\title{
SPATIAL DIMENSION OF TIMBER TRADE \\ IN THE APUSENI MOUNTAINS, ROMANIA
}

DOI: http://dx.doi.org/10.18509/GBP.2020.64

UDC: 339.3:674]:303.71(498)"2000/2018"

\author{
Adrian Gabriel Simion ${ }^{1,2}$, \\ Marian Marin ${ }^{1,2}$, \\ Cristian Mihnea Popa ${ }^{1,2}$, \\ Karina Andreea Gruia ${ }^{1,2}$, \\ Maruntelu Arina ${ }^{1,2}$; \\ ${ }^{1}$ University of Bucharest - Faculty of Geography, Bucharest, Romania. \\ ${ }^{2}$ Research Centre for Integrated Analysis and Territorial Management, Bucharest, Romania.
}

\begin{abstract}
The impact of the economic pressure on the forest fund is one of the main topics of debate in the public space, increasing the relevance of the analysis of the variables that define the problem being a constant concern of the scientific world. For this study we set out to analyze the spatial dimension of the timber trade from the territorial administrative units in the Apuseni Mountains, both spatially and in evolution, between 2000 and 2018. For this purpose, the statistical data regarding the timber trade were processed, so that it can be visualized at the level of territorial administrative unit, applying established GIS methods. The strings of statistical data were analyzed in evolution as well as spatial in relation to forest loss, information extracted based on the post-processed satellite images. Using both data sources, it was possible to make an administrative correlation between the evolution of forest loss and the commercially registered wood trade. In order to obtain real and relevant information regarding the dynamics of timber trade in the studied region, it is necessary to correlate this information with the dynamics of the forestry fund in the region. The results showed contradictions between the cleared surfaces and the participation of the administrative units where the cleared and their revenues from the wood trade were cleared.
\end{abstract}

Keywords: Wood trading, Forest dynamics, deforestation, forest loss evolution

\section{INTRODUCTION}

Forest exploitation plays an important role in the development of the local economic profile, the forest practices being a result of the presence of this resource in the area, but also directly influenced by the major economic or political events. Excessive exploitation can create imbalances in territorial systems.

Among the most important reasons that who contributed to the forest area inbalances are the legal and illegeal logging [1], [2], [3].

As general matters the first consequence of deforestation is the soil erosion acceleration [4], [5], [6]. The increased erosion rate in areas where the forest was cleared was higher especially where there was a higher degree of slope but also favorable climatic conditions [7], [8], [9], [10].

Another cause caused by the removal of forest vegetation has led to an increase in global $\mathrm{CO} 2$ concentration in the atmosphere but also the acidity of the planetary ocean, causing a negative global impact [11], [12]. 
Protecting and monitoring the evolution of forest areas is an international concern that is reflected in different monitoring programs or methods and techniques that are necessary taking into account the effects of these practices [13]. Of all the methods for analyzing and measuring forest surfaces, satellite imaging and GIS methods have proven to be the most efficient and efficient [14], [15], [16], [17], [18], [19].

Romania is one of the European countries that has natural virgin forests but also many protected areas that are part of the European national program Natura2000, areas which are mainly in mountain areas such as the Apuseni Mountains [20], [21].

One of the political events with great impact on the forest dynamics was the fall of the communist regime in Romania [22]. In Romania, the main causes of deforestation are for timber export but also for home heating, being very important for the rural population [23],[24]

In this study we set out to analyze the spatial dynamics of timber trade economic data in a dynamic correlation to see if there is a common pattern for both the evolution of economic indicators and the evolution of forest surfaces.

\section{METHODS}

The area of study we have chosen includes the Apuseni Mountains, which is part of the Western Carpathians, the shortest and most complex Carpathian sector in Romania. The Apuseni Mountains sit between Mureș River (South), Someș River (North) [25]. From an administrative point of view, it intersects with 6 counties, Bihor County, Cluj County, Alba County, Hunedoara County, Arad County and Sălaj County and around 171 administrative units (Figure 1).

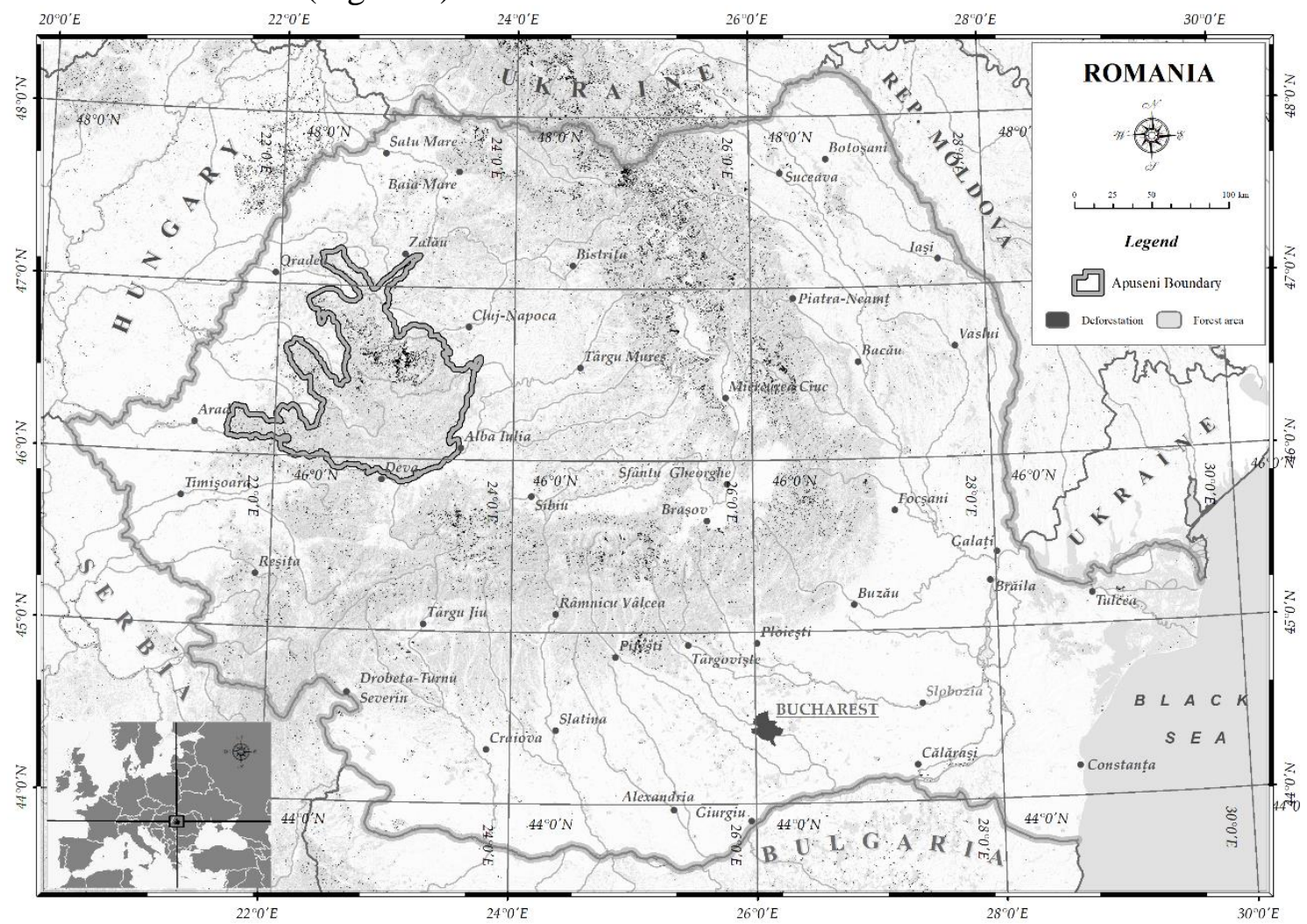

Figure 1. Study area 


\section{Data processing}

This study was achieved using a national economical database and an international database published by the Department of Geographic Science, Maryland University, named Global Forest Change (GFC). GFC is a database resulted from Landsat image analysis and processing that produce the dynamics of forest loss as a main dataset, and a 2000-year image of forest area and 2012 image of forest gain area. GFC database is made of three processed images, 2000 forest tree image, named treecover2000, that shows the tree cover density between 0 and 100, an image that shows the forest gain area, named gain, that gathers forest gain between the first year of analysis, 2000, and 2012. The last dataset and the main one is the image of forest loss, which is named lossyear. Lossyear is the only image that shows a year by year report from 2000 and 2018, practically showing the missing forest area for each year. The images are generated as GeoTIFF format and were post-processed for the whole Romania and for the study area in order to be spatial joined to the Territorial Administrative Units of the Apuseni Mountains. The Lossyear image is provided as an image with a pixel value of $0-18$ where 0 means no data and the values between 1-18 mean each year for which the change detection was performed. The image analysis and processing were done with ArcGIS in order to obtain areas for each Administrative unit overlapping the study area and for the spatial analysis of the datasets used, and joining with the wood trading economic dataset,

\section{RESULTS}

Analyzing all the economic data and the Lossyear data that shows forest loss evolution, we obtain the following results:

\section{Wood trade turnover $-2000-2018$}

Following the analysis of the economic profile of Apuseni Moutains, by extracting the wood trade turnover we found that the settlements with the higher turnover value are the main cities of the area and the settlements placed at the border of the analyzed region. According with the evolution from the Figure 2, just $10 \%$ of the settlements were dealing with wood trading at the beginning of 2000 years, followed by an increase to $41 \%$ in 2008, 44\% in 2009 and 37\% in 2018. Year 2008 marks the beginning of the Great Global Economic crisis.

\section{Wood trade companies evolution - $2000-2018$}

From the same economic dataset, we extracted the number of companies that were dealing with wood trade in the analyzed period. We observed a pattern of evolution from 20002018 direct proportional with the turnover. Year 2000 in just $13 \%$ of the settlements were companies registered as wood trade companies (57 companies). In 2008 we can see an increase of the number of settlements with companies in this economic sector (269 companies), at 46\%. Year 2009 keeps the trend rising at $48 \%$ of Apuseni Mountains settlements with 279 companies, and decreasing at $43 \%$ in 2018 with 211 companies (Figure 3). 


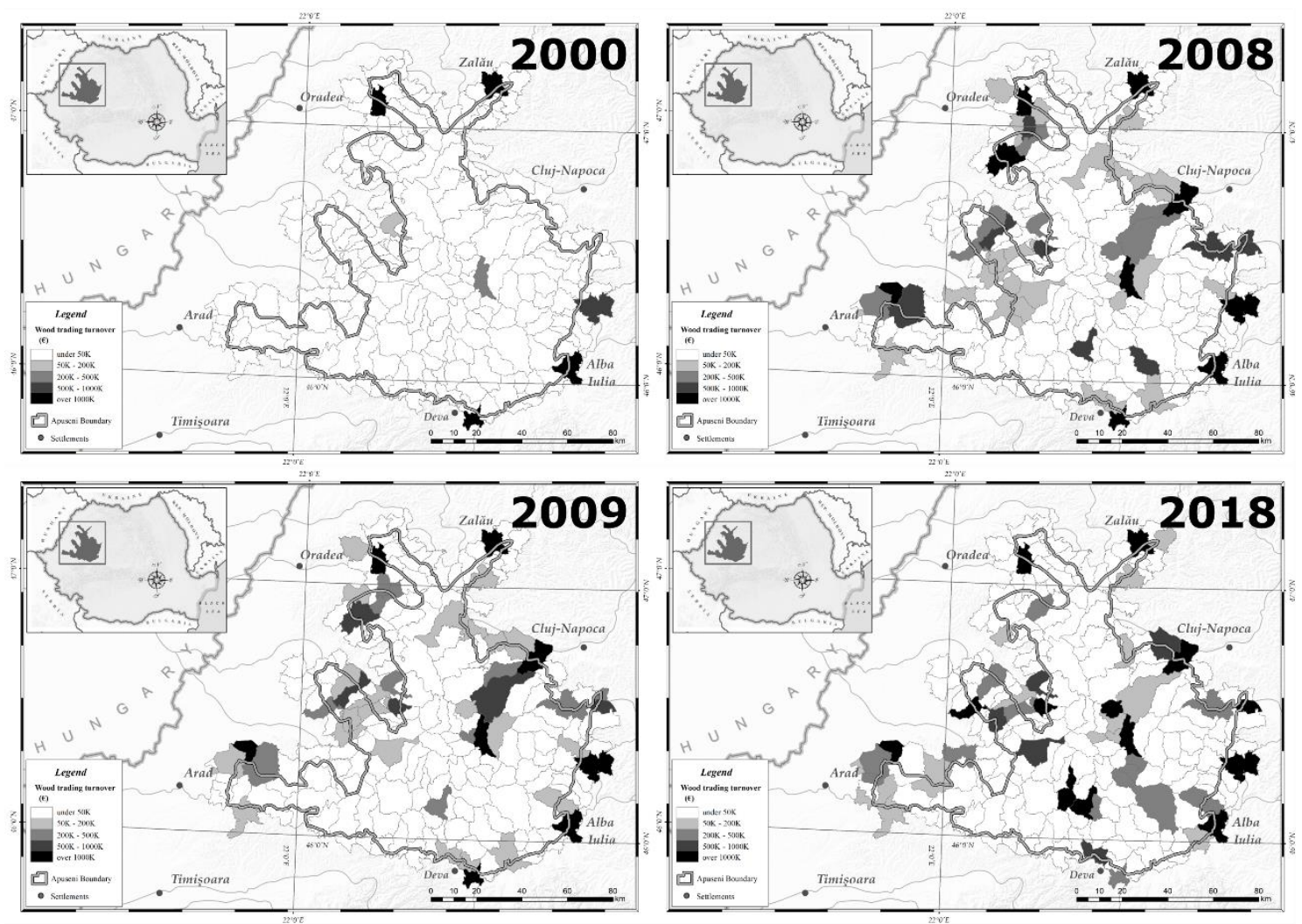

Figure 2. Choropleth maps of wood trade turnover evolution 2000 - 2018

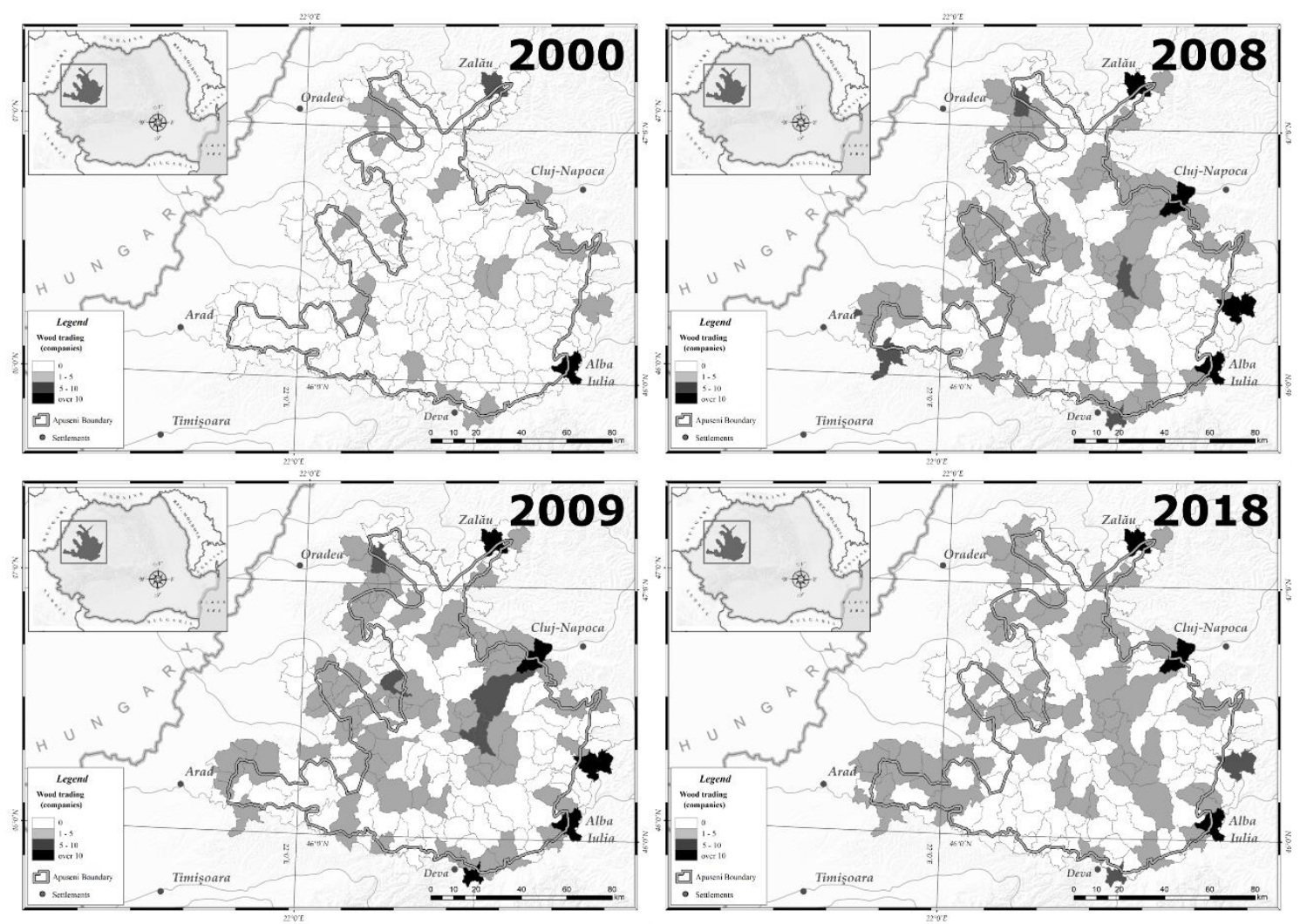

Figure 3. Choropleth maps of wood trade companies evolution 2000 - 2018 


\section{Lossyear - forest loss overview 2018}

By reporting the loss area of forest from the analyzed images described, at the administrative unit level (settlements) we can observe that the settlement with the highest forest loss area are placed in the Northern region of the Apuseni Moutains, region known by its higher altitudes and coniferous vegetation [25], (Figure 4).

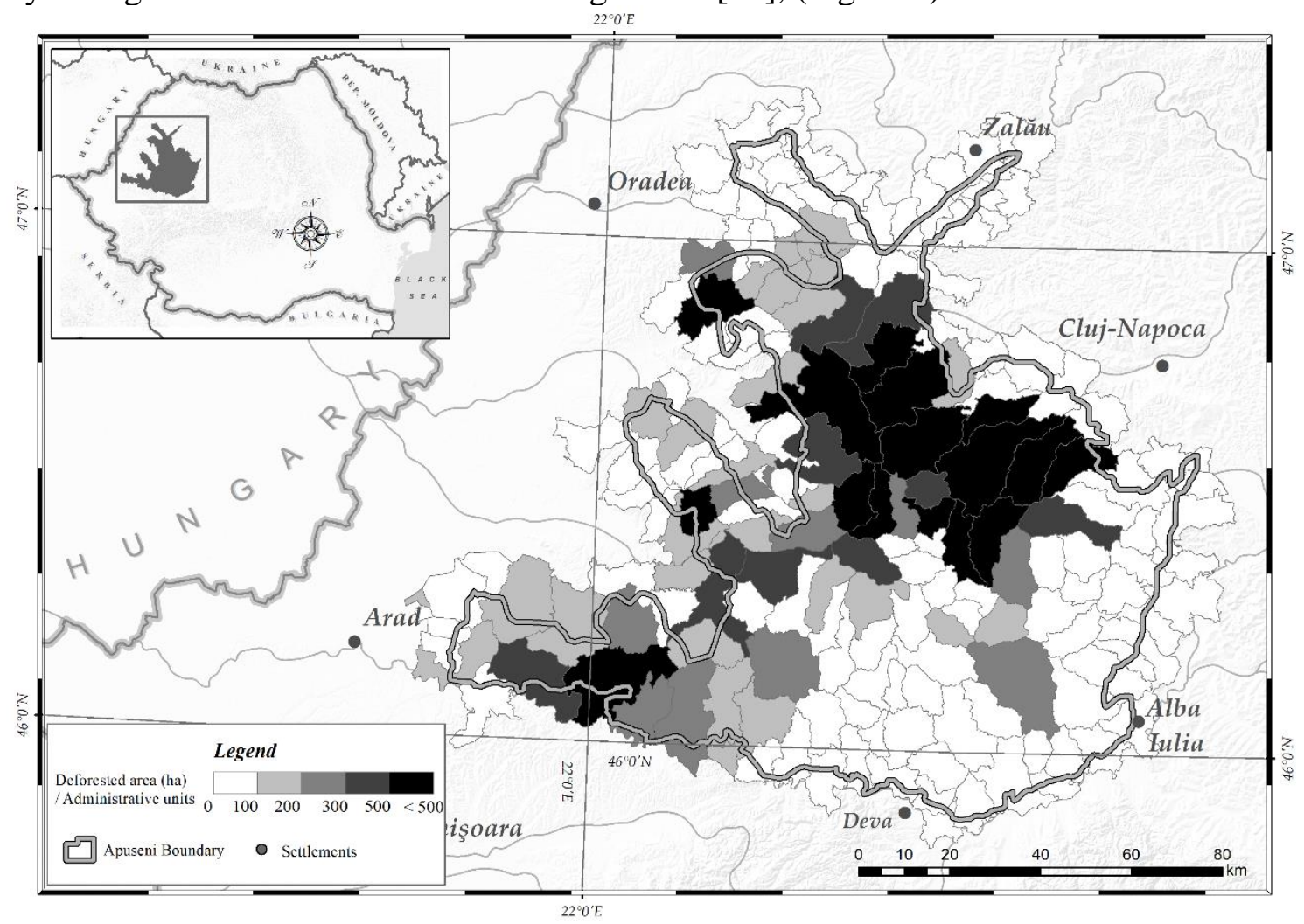

Figure 4. Choropleth maps of forest loss evolution $2000-2018$

\section{Comparison between the wood trade turnover}

\section{evolution and the forest loss evolution between 2001-2018}

Comparing the evolution of both forest loss area and turnover from the settlements placed in the Apuseni Mountains, we can observer some similarities in the evolution pattern somewhere between 2006-2008. The link between the two evolutions is the Great Global Economic crisis from that period of time. Even that the forest area evolution decrease after 2008 and it has some other increases in 2012 and 2017, the general trend is decreasing, while the turnover evolution is obviously increasing each year despite the economic crisis.
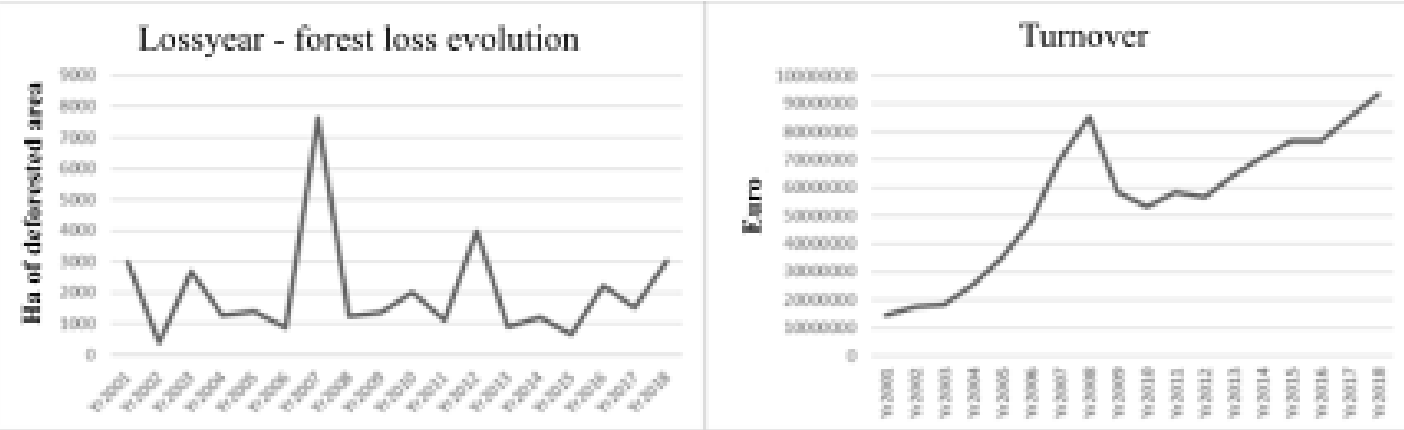

Figure 5. Forest loss evolution $2001-2018$ 


\section{CONCLUSIONS}

The results confirmed that it exists a correlation between the imagery forest loss evolution and the evolution of the economic official data, such as wood trade turnover and wood trade number of companies. At the same time to obtain accurate information regarding the forest loss dynamics from a give region, it is necessary to approach a methodology that uses the appropriate data sources for the needed results. Because there are no official national data regarding the forest loss evolution or deforestation, this kind of Landsat based database is very useful to be correlated with official economic data as turnover, income, companies or employees from a certain economic sector.

The methodology used in this study by correlating forest dynamics with the wood trade statistics provides a plus in the research. As a general number of affected settlements, the results showed some contradictions between the number of deforested settlements and the number of settlements with registered companies or turnover from wood trading, but the general overview and statistical evolution showed that the turnover and the forest loss evolution are correlated in the evolution pattern. At the same time this study shows that it exists a correlation between the type of forest preferred in the wood trading, by placing wood trade companies near the coniferous area from Apuseni Mountains.

\section{REFERENCES}

[1]. Ciobotaru, A.M.; Andronache, I.; Ahamme, H.;, Jelinek, H.F.; Radulovic, M.; Pintilii, R.D.; Peptenatu, D.; Drăghici, C.C.; Simion, A.G.; Papuc, R.M., Marin M.; Radu, R.A.; Grecu, A.; Gruia, A.K.; Loghin, I.V.; Fensholt, R.; Recent Deforestation Pattern Changes (2000-2017) in the Central Carpathians: A Gray-Level Co-Occurrence Matrix and Fractal Analysis Approach. Forests, 2019, 10, 308.

[2]. Draghici, C.C.; Peptenatu, D.; Simion, A.G.; Pintilii, R.D.; Diaconu, D.C.; Teodorescu, C.; Papuc, R.M.; Grigore, A.M.; Dobrea, C.R. Assessing economic pressure on the forest fund of Maramures County - Romania, J For Sci, 2016, 62, 175-185.

[3]. Draghici, C.C.; Andronache, I.; Ahammer, H.; Peptenatu, D.; Pintilii, R.D.; Ciobotaru, A.M.; Simion, A.G.; Dobrea, R.C.; Diaconu, D.C.; Visan, M.C.; Papuc, R.M. Spatial evolution of forest areas in the northern Carpathian Mountains of Romania. Acta Montan Slovaca, 2017, $22,95-106$.

[4]. Langerwisch, F., Walz, A., Rammig, A., Tietjen, B., Thonicke, K., Cramer, W. Deforestation in Amazonia impacts riverine carbon dynamics. Earth Syst Dynami, 2016, pp 953-968.

[5]. Karamage, F., Shao, H., Xi Chen, X., Ndayisaba, F., Nahayo, L., Kayiranga, A., Omifolaji, J. K., Liu, T., Zhang, C. Deforestation Effects on Soil Erosion in the Lake Kivu Basin, D. R. Congo-Rwanda, Forests, 2016, 7(11):281.

[6]. Yang, D., Kanae, S., Oki, T., Koike, T., Musiake, K. Global potential soil erosion with reference to land use and climate changes, Hydrol Process, 2003, pp 2913-2928;

[7]. Bell, M., Boardman, J. Past and Present Soil Erosion (Oxbow Monograph). Oxbow Books, Oxford, 1992.

[8]. Lufafa, A., Tenywa, M. M., Isabirye, M., Majaliwa, M. J. G., Woomer, P. L. Prediction of soil erosion in a Lake Victoria basin catchment using a GIS-based universal soil loss model. Agric Syst, 2003, pp 883-894.

[9]. Nachtergaele, F., Petri, M., Biancalani, R., Van Lynden, G., Van Velthuizen, H., Bloise, M. Global Land Degradation Information System (Gladis); Beta Version. An Information Database for Land Degradation Assessment at Global Level. Land Degradation Assessment in Drylands Technical Report; Food and Agriculture Organization of the United Nations (FAO), 2010, vol 17. 
[10]. Karamage, F., Shao, H., Xi Chen, X., Ndayisaba, F., Nahayo, L., Kayiranga, A., Omifolaji, J. K., Liu, T., Zhang, C. Deforestation Effects on Soil Erosion in the Lake Kivu Basin, DR CongoRwanda, Forests, 2016, vol 7(11):281.

[11]. Villarino, S. H., Studderta, G. A., Baldassini, P., Cendoya, M. G., Ciuffoli, L., Mastrángelo, M., Piñeiro, G. Deforestation impacts on soil organic carbon stocks in the Semiarid Chaco Region, Argentina, Science of The Total Environment, 2017, pp 1056-1065.

[12]. Langerwisch, F., Walz, A., Rammig, A., Tietjen, B., Thonicke, K., Cramer, W. Deforestation in Amazonia impacts riverine carbon dynamics. Earth Syst Dynami, 2016, pp 953968.

[13]. Olabemiwo FA, Danmaliki GI, Oyehan TA, Tawabini BS (2017) Forecasting CO2 emissions in the Persian Gulf States. Global J Environ Sci Manage 3(1):1-10. doi: 10.22034/gjesm.2017.03.01.001.

[14]. Winkel, G., Blondet, M., Borrass, L., Frei, T., Geitzenauer, M., Gruppe, A., Jump, A., Koning, J., Sotirov, M., Weiss, G., Winter, S., Turnhout, E. The implementation of Natura 2000 in forests: A trans- and interdisciplinary assessment of challenges and choices. Environmental Science \& Policy, 2015, pp 23-32.

[15]. Hansen, M. C., Potapov, P. V., Moore, R., Hancher, M., Turubanova, S. A., Tyukavina, A., Thau, D., Stehman, S. V., Goetz, S. J., Loveland, T. R., Kommareddy, A., Egorov, A., Chini, L., Justice, C. O., Townshend, J. R. G. High-Resolution Global Maps of 21st-Century Forest Cover Change. Science, 2013, pp 850-853.

[16]. Prăvălie, R., Sirodoev, I., Peptenatu, D. Detecting climate change effects on forest ecosystems in Southwestern Romania using Landsat TM NDVI data. Journal of Geographical Sciences, 2014, vol. 24, pp 815-832.

[17]. Petrisor, A. I., Petrisor, L. E., 2006-2012 Land cover and use changes in Romania - an overall assessment based on Corine data. Present Environment and Sustainable Development, 2017, vol 11, pp 119-127.

[18]. Borrelli, P., Panagos, P., Märker, M., Modugno, S. and Schütt, B. Assessment of the impacts of clear-cutting on soil loss by water erosion in Italian forests: First comprehensive monitoring and modelling approach, Catena,2017, vol 149 (3), pp 770-781.

[19]. Beaudoin, G., Rafanoharana, S., Boissiere, M., Wijaya, A., Wardhana, W. Completing the Picture: Importance of Considering Participatory Mapping for REDD plus Measurement, Reporting and Verification (MRV), Plos One, 2016.

[20]. Andronache I., Fensholt R., Ahammer H., Ciobotaru A. M, Pintilii R.D., Peptenatu D., Draghici C.C., Diaconu D.C., Radulovic M., Pulighe G., Azihou A.F, Toyi M.S., Sinsin B., 2017. Assessment of Textural Differentiations in Forest Resources in Romania Using Fractal Analysis. Forests; 8(3):54. https://doi.org/10.3390/f8030054.

[21]. Romanian Environment Ministry - www.mmediu.ro

[22]. Pintilii R.D., Andronache I., Diaconu D.C., Dobrea R.C., Zelenakova M., Fensholt R., Peptenatu D., Draghici C.C., Ciobotaru A. M., 2017. Using Fractal Analysis in Modeling the Dynamics of Forest and Economic Impact Assessment: Maramureș County, Romania, as a Case Study. Forests, 8(1):25. doi:10.3390/f8010025.

[23]. Pintilii R.D., Andronache I., Simion A.G., Draghici C.C., Peptenatu D., Ciobotaru A.M., Dobrea R.C., Papuc R.M., 2016. Determining forest fund evolution by fractal analysis (SuceavaRomania). Urbanism Arhitecture Constructions, 7(1):31-42.

[24]. FAO. State of the World ís forests. 2014, Forest and Agriculture: Land -Use challenge and opportunities. Rome, Italy. http://www.fao.org/3/a-i5588e.pdf.

[25]. Roșu A., Geografia Fizică a României (1973), Editura DIDACTICĂ ȘI PEDAGOGICĂ, București, 433 pag. 